\title{
10
}

\section{Consumption, global humanitarianism and childhood}

\author{
Laura Suski
}

The notion of political consumption suggests that our everyday practices of consumption are ethical practices. It may be argued that these ethical practices become more important when children are involved as it is often argued that our ethical obligations to children require protection and care. As political consumers, we might seek actions such as protecting 'our' children by purchasing environmentally friendly products, or we might act against child labour practices in 'distant' nations by purchasing garments manufactured by particular companies. These practices raise several questions of a global humanitarianism for children. Can the intent to protect 'our' children extend to a more universalised impulse to protect 'other', more distant children? What are the limitations of political consumerism as a channel for a humanitarian impulse? Can the everyday practice of consumption be a space of care and concern for international justice?

In this chapter, I bring these questions to the analysis of the consumption of children's toys and the online discussions of boycotting 'unsafe' toys. I explore how a neoliberal parenting culture in the West, which promotes a highly individualised and intensive model of parenting, affects a more universal and collective call for a global international humanitarianism. While social media provides opportunities to share and discuss information about toy safety, it will be argued that emotion is an important part of humanitarian mobilisation, and that the emotions of consumption are often thwarted by the identity politics of consumption.

\section{Distance, care and the political consumer}

The landscape of contemporary consumption practices includes practices considered 'ethical' responses to the myriad of problems that have come to mark global consumption. Political consumption recognises the power of consumers to use their spending power to alter such things as the labour relations behind products, the 'green' or organic content of products, the health of local economies, the safety of products and the treatment of animals in the production process. The varied spaces 
of political consumerism make it very difficult to draw parallels between forms of political consumption like boycotting, the refusal to buy certain products, and buycotting, choosing to support one product over another. What, for example, is the relationship between the consumer who purchases carbon offsets for her recent flight to Greece, and the consumer who purchases second-hand clothes at the local thrift store?' Political consumerism may also be gendered in that women and men may be affected by different factors including levels of trust in organisations and corporations. ${ }^{2}$ Moreover, while political consumerism can be used to create more ethical consumption, 'it can also be a tool to support nationalism, intolerance, exclusiveness, or other types of hatred. ${ }^{3}$

A recurrent theme in the analysis of ethical consumption is the claim, or worry, 'that it reflects a substitution of publicly oriented collective participation by identitybased, individually motivated and privatized forms of concern.' ${ }^{4}$ This theme is made more acute if we are asking consumers to think about global collectivities. As Jo Littler points out, certain versions of anti-consumerism can lead to a 'quasi-pathology of consumerism heroism' and to 'more individualized solutions than the modes of consumption that they critique.'s Global ethicists have always had to contend with the question of how far our ethical obligations extend, and whether such obligations could ever trump obligations to those closest to us. In the early 1970s, utilitarian philosopher Peter Singer asked what our obligations might be to distant sufferers of famine. Acknowledging that we first have responsibilities to our family, he personally practised the maxim that we should move to channel our personal surpluses to those who need it anywhere in the world, and in this sense we should 'give until it hurts. ${ }^{6}$ For Singer, the utilitarian maxim is transportable in that we must look beyond the needs of our own society. Adam Smith (1759) raised the question of indifference for the suffering of distant others in his eighteenth-century work The Theory of Moral Sentiments. Asking his readers to compare the experience of losing a little finger to an earthquake in China, he presented the model of an inner impartial spectator that was capable of a form of reasonable sympathy that was both mobile and capable of moving men out of self-love.7 Given the profound difficulty of traversing differences in geography and privilege, it makes sense that Adam Smith was absorbed by sympathetic identification as critical to his eighteenth-century model of the impartial spectator. Cosmopolitan sentiments, however, can be highly sentimentalised and problematic. As Sonia Bookman points out in her analysis of contemporary emotional branding and the urban 'consumptionscape' of coffee, everyday consumers of coffee build their own affective experiences of coffee where the "love of coffee is extended to a "care"

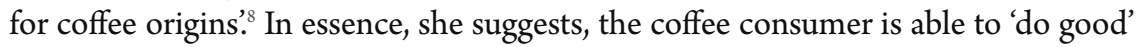
through cosmopolitan branding because he or she gets to act out feelings of care and empathy, and in turn, gain more pleasure in the consuming activity.

One might argue that today's consumer may not need to work very hard to feel connected to distant issues. Sites such as 'sweatfreeshop.com' provide resources for shoppers to avoid problematic brands. Personal blogs dedicated to minimalism and 
ecofriendly living can also direct people to local fashion brands. If such information is readily available to those who Google, or follow blogs, Twitter or Facebook feeds, it begs the question if one may even need sympathetic identification to connect with distant strangers? Faced with the facts of problematic consumption, won't the global consumer who is inclined towards ethical consumption simply make reasonable decisions about what to consume, particularly if such facts are delivered by a Facebook friend or a curated newsfeed?

Discussing the case of a wave of sit-ins and protests by the indignados to the economic crisis in Spain in 2011, Paolo Gerbaudo refers to a 'harvesting of indignation' by social media like Facebook and Twitter, and explores how such media 'contributed to transforming individual sentiments of anger into a collective identity animated by a desire to take back the streets after years of demobilisation.' Gerbaudo insists that we not see social media in purely 'cognitivist' way as a 'network of brains', and rather, argues for the need to 'recuperate a sense of the body and the emotions in the process of contemporary mobilisation. ${ }^{10}$ As he examines various movements of 2011, including the Arab Spring, he stresses the 'emotional coalescence of the people' and refuses to see social media as merely an informational conduit. ${ }^{11}$

My focus in this chapter, and indeed in my other work around humanitarianism, is the emotional and social character of humanitarianism. ${ }^{12} \mathrm{I}$ argue that it is important to see humanitarianism as a social configuration of moral actors, and to see that social configuration as embedded in a politics of emotion. In her compelling history of human rights, Lynn Hunt argues, the claim that human rights are 'self-evident' relies on an 'emotional appeal' because 'it is convincing if it strikes a chord with each person.13 Global humanitarianism requires a breaking down of distance between humanitarians and so-called victims and emotion plays a large role in breaking down this distance.

On the question of consumer action, we can see an intersection in debates in the scholarships around online activism and global humanitarianism. While it is true that global capitalism makes possible material connections between consumers, and while we can be informed of these connections more quickly and easily through digital networks, these connections do not fully explain why we respond to some calls for action and not others. We need to further unpack the sentiments that mobilise humanitarian action. An exploration of political consumption and childhood offers a window into the complex space of humanitarian mobilisation.

\section{Toys and the consumption of childhood}

While many have challenged historian Phillippe Ariès' confident claim that childhood was a 'modern invention', scholars have described an important shift in the understanding and the experience of childhood that took place with the spread of industrialisation, and the accompanying movement away from childhood as a period of labour: childhood became a period of innocence and play. ${ }^{14}$ Toys became 
part of this shift in that they affirmed childhood as a unique period in the life course, and middle-class homes soon sought out toys to affirm this 'ideal childhood. ${ }^{15}$ Researchers of consumption see children as occupying an important frontier for capitalist expansion. ${ }^{16}$ Childhood play has become fully 'capitalised' and children fully socialised as consumers, evidenced by such trends as the intersection of entertainment and merchandising, and by toys that necessitate collecting and cumulative consumption. Child-centred, open-ended imaginative play has been replaced by toys that limit play possibilities and necessitate consumption on the part of the child. ${ }^{17}$ In the spirit of work like Juliet Schor's Born to Buy (2004), childhood is a site where excessive consumption is intensified through a socialisation that occurs in the market. ${ }^{18}$ As Langer notes, at the end of the twenty-first century children's consumption works to re-inscribe children as 'sacred', this time due to their spending power. ${ }^{19}$

While it is clear that childhood takes place in the world of consumption, and that the market is implicated in the 'psychic formation of the child', there is much disagreement as to what this means for the consuming child. ${ }^{20}$ Despite the presence of childhood in many theories of consumerism, I concur with Daniel Thomas Cook's claim that such theories 'do not know childhood' and that most discussions of consumption have failed to provide a thorough account of the economic life of children. ${ }^{21}$ For example, classic sociological theorists of taste and consumption, such as Pierre Bourdieu, do not provide a serious treatment of children. ${ }^{22}$ Few contemporary theorists of consumption draw directly on accounts of the social lives of children, nor the cultural histories of childhood. ${ }^{23}$ Cook argues that we need to move beyond seeing the individual child as an independent economic actor, to a theory of consumption which sees contemporary children as participating in a social world in which they are already embedded as consumers, and that purchasing often 'takes place, for, in the name of, or with someone in mind other than the shopper. ${ }^{24} \mathrm{Cook}$ insists that children call into question the individuality of desire, identity, and lifestyle. ${ }^{25}$

The analysis of childhood consumption is also affected by the use of models of identity to understand consumption. An added analytical difficulty is that we are often presented with dichotomous models of shopping where the consumer is either an 'enraptured pleasure seeker' or a 'relationally constrained actor locked into a series of actions ${ }^{26}{ }^{26}$ Sociologist Zygmunt Bauman is wary of the identity politics of consumption where a fully commodified self replaces the citizen, and where mass consumption is affirmed as the only economic foundation of society. ${ }^{27}$ This debate dovetails neatly with discussions about 'new' and 'old' models of childhood socialisation. Where psychological and sociological theories of childhood development once saw the child as a passive sponge who simply absorbed socialisation, more recent theories see the child as an empowered agent in their own becoming. ${ }^{28}$ Mapped onto the analysis of consumption, this dichotomous reading of childhood development sees children as either exploited and manipulated consumers (along with the rest of us), or active agents in their own identity building through consumption. 
There are, however, answers to the impasse around consumer identity. As Dennis Soron argues in his discussion of sustainable consumption, there are promising ways to bring self-identity 'back in' without succumbing to a mere celebration of consumption, nor an overly individualist account of how consumer agency operates. He argues that we need to pay due attention to the ambivalent role of consumption in our daily lives: 'exploring the intersection of sustainable consumption and self-identity requires us to comprehend the constrained context and political limits of individual "green" lifestyle choices even as we engage sympathetically with the ethical and collectivist impulses underlying them.'. Again, Soron is clear that in approaching sustainable consumption through the analysis of identity we must continue to aim for 'reconstituting a social, collective and non-commodified basis for personal identity' ${ }^{30}$

If we take Cook's suggestion that we need to look at the social lives of children and move beyond the notion of children as independent economic actors, then it seems we should explore toy buying as part of parenting (noting, of course, that many children are active consumers in their own right). A key line running through Vivian Zelizer's book The Purchase of Intimacy (2005) is that we take the relationship between economics and intimacy seriously and see household economics as a social process through which household relationships are constructed..$^{31}$ As Charlotte Faircloth also insists, contemporary parenting is a project of identity work: 'In deciding how to dress, feed, put to sleep and transport their children, adults do not simply live their lives through children but, in part, develop their own identity through them. ${ }^{32}$ Thus, toy consumption can be seen as a space where the identity of parent is also constructed.

Privileged parents buying toys certainly occupy a unique space of consumer agency in that they no doubt experience some of the ambivalences around consumption as they both seek to provide a childhood of innocence and play for their children, while at the same time perhaps try to think ethically about how to provide this kind of childhood. One of the key aspects of the social lives of privileged children is the current dominance of a model of intensive parenting. According to scholars of childhood, this model of parenting mainly applies to privileged women as primary caregivers and suggests that mothers are to invest large amounts of time, money and energy into parenting, and that they should gather expert knowledge to build their parenting repertoire. ${ }^{33}$ Intensive parenting is also accompanied by what some call 'parental determinism' in which it is the parent alone who is considered responsible for the wellbeing and socialisation of the child, and in turn, the child is considered a product of parenting. ${ }^{34}$ In intensive parenting, the moral view is entirely parent to child, in particular, the mother to child relationship. As Glenda Wall notes, the intensification of parenting is wrapped up in a neoliberal logic which emphasises individual self-management and control. ${ }^{35}$ Intensive parenting also includes protecting children from risks, and the list of risks is ever increasing, even including parents as risk factors themselves. ${ }^{36}$ Given that it is promoted as an ideal 
form' of mothering, those mothers who are unable to follow the model, like lowincome mothers, can view intensive mothering as enforced and coercive. ${ }^{37}$

More recently, there has been some backlash against this model and greater discussion of the 'over protected child'. Journalist Lenore Skenazy, for example, has popularised the idea of 'free range parenting' where parents are encouraged to allow their children to take more risks and to resist the idea that their kids occupy a world of constant danger and threat. Frank Furedi's 2008 Paranoid Parenting, as another example, encourages parents to ignore the experts. Still, given that the model powerfully intersects with a popular embrace of the idea of a 'risk society', the individualisation upheld in neoliberalism, and the cultural approach to childhood as a period of innocence, contemporary parenting is still marked by the assumption that children demand constant protection by parents.

Toy consumption occurs in a particular kind of moral community that involves an intersection of parenting and consumption. Some buycotts and boycotts have successfully produced moral communities that join localised consumers with distant producers, and in turn, have contributed to initiatives to improve labour conditions for workers and more sustainable forms of production. However, due to the natures of contemporary childhood and parenting, toy consumption often works to separate and alienate consumers from producers, rather than bringing them into co-operation or connection. The moral economies of Western childhood that see children as vulnerable subjects in a society of risk and, in turn, in need of care and protection, can come into conflict with the moral economies of global consumption that require consumers to expand their moral vision. In short, the general push is often to protect children from the dangers of global consumption, rather than to bring them into a moral community that seeks to make social and political connections between so-called distant strangers. Still, I conclude that it is important to look at the example of toy consumption as it deepens the analysis of consumption and childhood, challenges idealised or romanticised notions of a global moral community, and allows for further exploration of consumption as a site of global citizenship.

How do toy consumers feel and care about the producers of the toys who are most often making toys in other 'distant' parts of the world? The case of a 2007 toy recall of a popular toy train series offers some preliminary insights. 'Thomas and Friends Wooden Railway Toys' is a series of trains made of wood and plastic, based on an early twentieth-century book series, and later developed into a television series in the 1970 . They are expensive toys; current prices for individual trains range from $\$ 15$ to $\$ 30$ Canadian dollars. The toys tend to be played with by younger children with the suggested age range being 2-7 years old. In $2007, \mathrm{RC}_{2}$, the company that made the internationally popular children's wooden train toys, recalled 1.5 million units as a result of the 'discovery' of lead-based paint in the trains. ${ }^{38}$ Most of the recalled units used red paint and all were manufactured in China. Consumers were told to send the trains back to receive a replacement. This recall came amongst a series of 
product recalls in China, including cases of tainted pet food, milk and toothpaste. In fact, a recent book, Not Just China, described 2007 as the 'year of the recall'.39 Other toy manufacturers like Mattel and Fisher Price were also embroiled in recalls that same year.

It is no doubt that the use of lead paint makes a toy a more dangerous plaything, particularly if flakes of lead paint are ingested. The WHO confirms that ingested lead can have dangerous impacts on the developing brains of young children, and even low levels can have neurological effects. There are a number of factors that contribute to higher concern for lead poisoning in children, including the fact that children absorb lead at greater rates than adults. While there are no safe levels of lead, it is difficult to assess the amount of risk involved with lead-painted toys, including the likelihood of paint being ingested and the amount of paint that would be needed to cause serious health concerns, particularly given that the effects of lead are cumulative. There is little evidence to suggest that the toys themselves caused health consequences, and in turn, that the recall is more of a case of a 'lead panic'. ${ }^{40}$

When the dangers of lead became known, many countries adopted legislation to limit the use of lead in consumer products and the environment. Lead gas and household lead paint, for example, is considered hazardous and it is no longer available in many countries around the world. Like most environmental risk stemming from the production of good, the dangers are greatest in the global South and amongst the poor: according to the WHO about one half of the burden of disease from lead occurs in the South-East Asia Region, with about one-fifth each in the Western Pacific and Eastern Mediterranean Regions. In addition to children, workers are at great risk due to continued, cumulative exposure. Workers who work with leaded paint, for example, can also bring it home to their families on their clothes in the form of dust. In North America, lead poisoning risks remain, particularly around older homes with deteriorating paint and increased dust.

How did parents respond to these recalls? If online conversations, parenting blogs and online comments sections are used as data, the overwhelming reactions were shock, anger and fear. One New York Times article quoted a mother discussing her son's attachment to the toys and her disappointment with the recall:

These are the kinds of things he takes to bed with him. He puts them in his pocket and he takes them to the store, he takes them in the car - everywhere ... You think that when you're buying a high-end toy like a Thomas the Tank Engine train, that you're getting something that has gone through all the proper channels to make sure it's a safe toy.

Another parenting blog responded with equivalent shock but also with annoyance:

I am utterly shocked that our consumer protection agency even allows these products imported into our country since we've known about the dangers of lead poisoning 
for $30+$ years. I am a working mom and additionally angry that I have to take the time to remove and replace these items and check for any poisoning in my children. I will sign a petition to ban any imported children's products that do not meet our own standards. Next time, buy german toys $!^{41}$

As parents who had purchased Thomas and Friends merchandise expressed fear and anger about the recall, some who had not purchased the toys took the opportunity to remind parents about the problems of mass-produced toys more generally. Comments to a Washington Post article included the following statement:

My 4-year-old has a drum kit, a group of stuffed animals, and a lot of outdoor toys (jump rope, bouncy ball, sidewalk chalk). I prefer her to use her imagination than have the toy companies imagine stuff at her, but now I have another level to be smug about.

Many respondents directed their outrage at the government for not protecting the interests and safety of their children; however, China and Chinese products also became vilified in the media. China was 'not to be trusted' and the general parenting lesson to be emphasised was that toys from China were to be avoided.

Amidst the mass of comments that spoke with anger that North American consumers should not have to worry about dangerous toys, there were a few voices that raised different concerns. For example, in response to an online discussion that included some anti-Chinese comments about the recall, one commentator noted: 'It's silly to blame this on China, and turn it into a question of nationalism. The company is American and listed on NASDAQ! Unless the lead paint was a conspiracy sponsored by the Chinese government with the goal of poisoning the youth of America through toys, try a different, valid argument to express your upset.'42

It makes sense that the first reaction of parents was to protect their children from harm, but why did it stop there? Why didn't any parents express concern about the workers who had to make such 'hazardous' toys or the communities that might be affected by increased exposure to lead paint? Why were consumers seemingly unable to expand their moral communities so as to think of themselves as part of a chain of production and consumption, as in other practices of ethical consumption? From this particular recall, no larger initiative of political consumerism seemed to emerge to eliminate the use of lead paint in countries around the world or to encourage better labour conditions. Nor did the recall seem to trigger an attempt to increase awareness about lead poisoning in the global North. No online petition was circulated by parents, and surprisingly, no initiative to formally boycott the company emerged.

The HIT company which owned Thomas the Train was not severely financially affected by the recall, though it reported losses in 2009. The company was later bought out by Mattel in 2011 for $\$ 680$ million. ${ }^{43}$ Most consumers seemed to return the specifically recalled trains with enough faith in the company that they felt assured that this would not happen again, and that they had effectively managed the 
risk. If, as consumer theory suggests, we can be 'attached to commodities in deeply ingrained, affectively charged ways', consumers seemed certainly attached to Thomas and Friends. ${ }^{44}$ The recall had impacted the sacred space of play and perhaps the key goal was simply to return play to an original state of innocence and joy. In this case, the feelings of anger and distrust that parents experienced did not function as moral emotions in that they did not work to fuel some kind of global ethical connection or some cosmopolitan feeling.

No doubt the fact that China is seen as an impenetrable nation where consumers can do little about the politics of production is responsible in part for a lack of discussion and concern amongst parents for the producers of the lead-painted trains. Consumers need to feel as if their actions will have an impact in order to feel motivated to act. ${ }^{45}$ Many consumers felt as if China and Chinese citizens have willingly accepted the risks that accompany the production of cheap goods. Moreover, this recall was one amongst many and consumers probably felt that a buycott or boycott would be futile. One key difference from other recalls at the time, however, was that Thomas and Friends made high-end toys that many parents assumed to be safe due to the price of the toys. Affluent North American mothers engaged in a practice of intensified parenting likely viewed the Thomas the Train recall as an affront to the already difficult task of parenting in a society of risk. Further, as Wall points out, the 1990 s saw a rise in the discussion of parents as the builders of children's brains.$^{46}$ One can only assume that the potential of lead poisoning would have been a double affront in this sense.

The space of child's play may be also an impenetrable moral space in that it highly guarded by parents themselves. Products like organic baby food or hemp clothes have little difficulty penetrating the insular parent-child relationship of intensive parenting as they promise increased safety and health for children, but other forms of political consumerism have a more difficult road. ${ }^{47}$ While intensive parenting seems a likely discourse for extending the moral vision of parents through empathetic identification with distant others, instead, the impetus seems to be for good parenting, not good collective citizenship. When parenting is consistently raised as the cause of all social ills, it is not that parents are accused of ignoring their roles as public citizens, but rather, that 'bad parents' are ignoring or failing at their role of raising future good citizens. One of the most serious problems of intensive parenting is that it is often a highly solitary process in that the parent themselves must know the child inside and out, and must act as the sole moral agent on the behalf of the child. This can breed distrust if parents become less and less able to trust other adults in the task of socialising the next generation. ${ }^{48}$ As one mother noted after the recall: 'That's the scariest thing, because now it makes me want to go out and test all their toys because ... I don't trust any of them.' While Arlie Hochschild's important work on emotional labour focused on the costs of emotional regulation in labour, her general lesson that emotional regulation comes with its costs is relevant; one of the emotional costs of intensive mothering may be the heavy burden of the constant regulation of worry and risk. ${ }^{49}$ 
Mel Y. Chen argues that 'lead stories' also require attention to race. The 'lead panics' of 2007, Chen notes, centred around images of vulnerable white middle-class children playing with suspect toys. While the company took legal responsibility for the recall, it was China that became the site of attention and blame. The apparent global movement of toxic lead emphasised 'its mobility through and against imperialistic spatializations of "here" and "there" ". ${ }^{\circ}$ Chen notes that the new lead panic can be understood in the discourse of 'contagion' which echoes a 'turn-of-the-century Orientalized threat to white domesticity'; parents, therefore, were guarding against not only the threat of lead, but voicing a concern for a vulnerable 'national body.'.1 As Chen also points out, the image of a vulnerable white child is promoted while the ongoing exposure of people of colour to risk is ignored: 'An environmental history of toxic objects must minimally register the gendered, laboring, and chronically toxically exposed bodies of globalized capital, which systematically bear less frequent mention in narratives of toxicity than the cautionary warnings from the seat of US empire. ${ }^{52}$ Chen's analysis encourages us to think carefully about the dangers of parenting narratives of protection, as such narratives can easily extend into nationalist narratives. Moreover, against the history of colonialism and empire, the global South becomes a reminder of unsafe versions of childhood that the global North has progressed beyond, and in turn, the connection is made that much harder.

If the space of political consumerism and toys demonstrates clashing narratives of parenthood, the tragic photographs of Alan Kurdi, a drowned Syrian boy, which circulated online in the fall of 2015, may offer a more unified narrative of parenting. The photographs were unique in their ability to galvanise concern for Syrian refugees in many parts of the world. It was a surprising galvanisation given that the photograph broke the powerful taboo of presenting a dead child in mainstream media. The taboo was even broken in headlines like the New York Times story ( 2 September 2015) that proclaimed 'A dead baby becomes the most tragic symbol yet of the Mediterranean refugee crisis'. In response to the New York Times story, one online reader simply articulated: 'I cried. I just cried. What are we?' While some viewers were not ready for such images, others saw the merits in publishing the photographs and were moved to action. How did these particular photographs move viewers, while hundreds of other photographs of refugees seemed to lead to indifference? One possible reason is that Alan Kurdi was an innocent victim who people could easily identify with, and who could easily be absorbed into a parenting narrative of cosmopolitan caring. He wore clothes that most parents in the West could recognise, and the beach on which his body lay seemed like a beach that anyone might visit on holiday. One comment on a Huffington Post story (2 September 2015) urges those engaged in the online debate to 'imagine themselves a parent to that child'. The protection of Alan Kurdi (and future Alan Kurdis) was not positioned as coming at the expense of the protection of children in the West. If anything, the tiny child in a red T-shirt and running shoes was already a child of the West in the eyes of many viewers. In Canada, Alan Kurdi became the call to increase the number of Syrian 
refugees, or put differently, to make him and others children of Canada. ${ }^{53}$ This kind of narrative is used successfully by many international NGOs, particularly those that employ a child sponsorship model. Donors are essentially engaged in restoring lost childhoods. ${ }^{54}$

There is a larger question haunting my analysis: does parenting a child make parents better global citizens? There is no easy answer to this question. Erika Languir's compelling art history of childhood, Imagining Childhood, offers us an important reflection in its concluding line that images in the Western tradition have 'always made plain that we are all childlike..$^{55}$ Our ethical encounter with our own children is always an ethical encounter with our own childhoods. If contemporary parenting cultures turn us inwards, and if political consumption leads to individualised identity politics, these inward turns may be more accentuated by the fact that the often unstable category of childhood is constructed by parents themselves. The inward push may be an obstacle for the apparent requirement of an outward pull for global humanitarian activism. Still, we can recognise this challenge. Jo Littler highlights the 'interior economies' of radical consumption politics and notes that we need to think more deeply about the models of 'reflexivity' that lead to activism..$^{6}$ While she sees promise in tools offered by cultural studies, she also recognises the need to move into 'wider' and more 'messy' terrain to explore how 'alternative economies elicit affectual investments (or not), ${ }^{57}$ Thus, to understand how and when media cultures support a global humanitarianism for distant children, our theoretical tools must include those that can unpack parenting culture, and the emotional economies that govern this culture.

\section{Conclusion}

When children are mentioned in reference to issues of inequality, it is often through the very possessive claim 'our children', implying that there are other people's children that are not of 'our' concern. Interestingly, the moral claims we make in the name of children often seek to stabilise them as moral subjects, as vulnerable and at risk. In the case of the toy train recall, there was a clear sense that middle-class and wealthy children could be protected from the risks that other children experience. The intensification of modern parenting is deeply at odds with a model of ethical consumption that requires that moral distance be overcome. Gaining knowledge of the working lives of others becomes even more difficult if we are witnessing a model of parenting that embraces a neoliberal, individualised notion of child as product.

If we are to understand how ethical consumption is practised and whether it holds promise as a way to shift from the individual to the collective, we cannot simply speak of connection as an abstract principle, and we cannot think of social media as simply erasing distance. Instead, we must see consumption practices as enacting social relations of care, responsibility and identity. The consumption of toys challenges the notion that cosmopolitan moral viewpoints can simply be willed 
into existence. In the case of the Thomas and Friends recall, parents took up a moral response that few ethicists would call them on: a fundamental desire to protect their children from harm. We need to think more deeply about whether protection of harm is the only moral reaction a parent can or should have to something like a toy recall. Exploring moral emotions requires us to see how emotion works to constitute people as legitimate and illegitimate objects of emotion. ${ }^{58}$

If a model of intensive parenting and the marking of childhood as sacred makes it difficult for parents to move from the personal to the collective, it seems fitting to end with a question that theorists of consumption have posed many times: Is the model of citizen consumer a dangerous one? Theories of consumption which recognise that children are not independent economic actors, and that speak to the complex emotional life worlds of childhood, will be better able to understand how morality can be built in the space of consumption. ${ }^{59}$ As Barnett et al. note, we need to speak of everyday consumption practices as 'ordinarily ethical', as practices through which we construct a life through negotiating practical choices about routine consumption..$^{60}$ While it is clear that childhood consumption requires a unique model of political consumerism, it also provides an important opportunity to explore a consumer identity where the identity being built, in this case the identity of parent, is already a volatile 'moral category'. The online responses to toy safety register a narrative of protection, but they also register deep anxieties amongst parents about being good parents. It would seem that consumption could easily be put in the service of global ethics if it involves consumers who are trying to be 'good parents'. Yet, as the analysis of toy consumption demonstrates, understanding the complexities of caring for those closest to us is critically important to the understanding of caring at a distance.

For scholars of global humanitarianism, we might refine the concluding question further and ask if a model of humanitarian as consumer is a dangerous one? Scholars of humanitarianism have long pointed out the important historical connections between the rise of global capitalism and global humanitarianism, paying particular attention to nineteenth-century anti-slavery movements as an emblematic example. ${ }^{61}$ This scholarship has not typically reduced the humanitarian to consumer as the critical question for global humanitarianism is not whether or not global connections exist, but rather how and when such connections mobilise social and political action. I conclude that the emotional landscape of consumption offers the possibility of mobilising action when the sentiment itself can travel, and in this sense, we need to speak of 'affective' models of connection. Media cultures may well provide connection between humanitarians and so-called victims, but as in the historical lessons of the past, connection alone is not enough. The case of children's toys demonstrates that in the face of apparent threat, we can seek to guard national and domestic borders, and deny such connection. Distant vulnerable children may trigger powerful rescue narratives, but close, apparently vulnerable children trigger equally powerful narratives of protection. Perhaps, then, the greatest danger to a 
global humanitarianism that seeks a more radical vision of justice, is not the embracing of a consumer identity, but rather, a neoliberal discourse of parenting in which the spectre of risk only serves to incite the emotion of fear.

\section{Notes}

1 Given the great variety of moral problems that face consumers, the term 'ethical consumption' is clearly a problematic catch-all term for this range of practices, and as T. Lewis and E. Potter note, the field of ethical consumption mirrors this in its 'inchoate' drawing on political economy, sociology, philosophy and cultural studies. See 'Introducing Ethical Consumption', in T. Lewis and E. Potter (eds), Ethical Consumption: A Critical Introduction (Oxon and New York: Routledge, 2013), p. 5. Jo Littler also notes that a distinction between moralism and morality is important to the analysis of consumption. See Radical Consumption: Shopping for Change in Everyday Life (Maidenhead: McGraw-Hill, Open University Press, 2009), p. 14. In this chapter I will use the general terms 'political consumerism' and 'ethical consumption' with the recognition that this may simplify a complex philosophical space.

2 L. Nielson, 'Buycott or Boycott? Understanding Political Consumerism', Journal of Consumer Behaviour, 9 (2010), pp. 214-27. Certain practices, like boycotting, have become feminised in that they are more often performed by women. See D. Stolle and M. Micheletti, Political Consumerism: Global Responsibility in Action (New York: Cambridge University Press, 2013), p. 77. Some research has shown that fathers are more critical of 'hyper-materialism' than mothers. See F. Shirani, K. Henwood and C. Coltart, 'Meeting the Challenges of Intensive Parenting Culture: Gender, Risk Management, and the Moral Parent', Sociology, 46:1 (2012), pp. 25-40.

3 Stolle and Micheletti, Political Consumerism, p. 39.

4 C. Barnett, P. Cloke, N. Clarke and A. Malpass, Globalizing Responsibility: The Political Rationalities of Ethical Consumption (Hoboken: Wiley-Blackwell, 2011), p. 212.

5 Littler, Radical Consumption, p. 77, emphasis in original.

6 P. Singer, 'Famine, Affluence and Morality', Philosophy and Public Affairs, 1:3 (Spring 1972).

7 A. Smith, The Theory of Moral Sentiments (Indianapolis: Liberty Fund, 1984 [1759]).

8 S. Bookman, 'Feeling Cosmopolitan: Experiential Brands and Urban Cosmopolitan Sensibilities', in D. Spencer, K. Walby and A. Hunt (eds), Emotions Matter: A Relational Approach to Emotions (Toronto: University of Toronto Press, 2012), p. 250.

9 P. Gerbaudo, Tweets and the Streets: Social Media and Contemporary Activism (London: Pluto Press, 2012), p. 77.

10 Gerbaudo, Tweets and the Streets, p. 77.

11 Gerbaudo, Tweets and the Streets, p. 160.

12 See, for example, L. Suski, 'Children, Suffering and the Humanitarian Appeal', in R. A. Wilson and R. D. Brown (eds), Humanitarianism and Suffering: The Mobilization of Empathy (New York: Cambridge University Press, 2009), pp. 202-22, and L. Suski, 'Humanitarianism as a Politics of Emotion', in D. Spencer, K. Walby and A. Hunt (eds), Emotions Matter: A Relational Approach to Emotions (Toronto: University of Toronto Press, 2012), pp. 124-36.

13 L. Hunt, Inventing Human Rights: A History (New York: W. W. Norton and Company, 2007), p. 26.

14 P. Ariès, Centuries of Childhood (Harmondsworth: Penguin Books, 1960).

15 G. Cross, 'Toys', in P. Fass (ed.), Encyclopedia of Children and Childhood: In History and Society, Vol. 3 (New York: Macmillan Reference, 2004), Web Version. 
16 B. Langer, 'Commodified Enchantment: Children and Consumer Capitalism', Thesis Eleven, 69 (2002), pp. 67-81.

17 Some research suggests a less passive model of consumption under capitalism whereby children join some adults as 'creationist' consumers in that they are active in the production of what they consume. See Minna Ruckenstein's study of Habbo Hotel, an online gaming world for children and teenagers: 'Children in Creationist Capitalism', Information, Communication and Society, 14:7 (2011), pp. 1060-76.

18 J. Schor, Born to Buy: The Commercialized Child and the New Consumer Culture (New York: Scribner, 2004).

19 Langer, 'Commodified Enchantment', p. 78.

20 Langer, 'Commodified Enchantment', p. 73. Of course, it must also be noted that many children around the world exist outside of this model precisely because they do not figure at all in practices of consumption.

21 D. T. Cook, 'The Missing Child in Consumption Theory', Journal of Consumer Culture, 8:2 (2008), p. 219.

22 P. Bourdieu, Distinction: A Social Critique of the Judgement of Taste, trans. Richard Nice (Cambridge, MA: Harvard University Press, 1984).

23 See for example Z. Bauman, Consuming Life (Cambridge: Polity Press, 2007).

24 Cook, 'The Missing Child in Consumption Theory', pp. 232, 234.

25 Cook, 'The Missing Child in Consumption Theory', p. 235.

26 T. Edwards, Contradictions of Consumption: Concepts, Practices and Politics in Consumer Society (Buckingham: Open University Press, 2000), p. 107.

27 Z. Bauman, Liquid Modernity (Cambridge: Polity Press, 2000); Bauman, Consuming Life.

28 For a review of these debates, see I. Frønes, The Autonomous Child: Theorising Socialization (New York: Springer, 2015).

29 D. Soron, 'Sustainability, Self-Identity, and the Sociology of Consumption', Sustainable Development, 18:3 (2010), p. 179.

30 Soron, 'Sustainability, Self-Identity, and the Sociology of Consumption', p. 180.

31 V. A. Zelizer, The Purchase of Intimacy (Princeton: Princeton University Press, 2005).

32 C. Faircloth, Militant Lactivism? Attachment Parenting and Intensive Motherhood in the UK and France (Oxford: Berghahn Books, 2013), p. 33.

33 F. Shirani, K. Henwood and C. Coltart, 'Meeting the Challenges of Intensive Parenting Culture: Gender, Risk Management, and the Moral Parent', Sociology, 46:1 (2012), pp. 25-40.

34 Wall argues that the re-emergence of an interest in attachment parenting makes the intensification of parenting abundantly clear. Gone are the biological claims that came with the classic research of John Bowlby. These claims are replaced by an attachment that must be constantly built and monitored by the parent, again, largely mothers (Conference presentation, Annual Meetings of the Canadian Sociological Association, Brock University, 2014).

35 G. Wall, 'Mothers' Experience with Intensive Parenting and Brain Development Discourse', Women's Studies International Forum, 33:3 (2010), pp. 253-63.

36 A. Romagnoli and G. Wall, "I know I'm a good mom”: Young, Low-Income Mothers' Experiences with Risk Perception, Intensive Parenting Ideology and Parenting Education Programmes', Health, Risk and Society, 14:3 (May 2012), pp. 273-89.

37 Romagnoli and Wall, ' 'I know I'm a good mom”, p. 286.

38 See www.cpsc.gov. Accessed 14 July 2017.

39 H. Babuji, Not Just China: The Rise of the Recall in the Age of Global Business (New York: Palgrave Macmillan, 2011). 
40 Mel Y. Chen, Animacies: Biopolitics, Racial Mattering, and Queer Affect (Durham, NC and London: Duke University Press, 2012).

41 www.jumpingmonkeys.com/jumpingmonkeys/2007/06/thomas_train_re.html. Accessed 14 July 2017.

42 S. Garfinkle, 'Choo on this', Washington Post (13 June 2007), http://voices.washingtonpost. $\mathrm{com} /$ parenting/2007/06/not_the_trains.html. Accessed 14 July 2017.

43 Note that the recall was not mentioned in major news pieces about the Mattel purchase of the company. See for example B. Barnes, 'Thomas the Tank Engine to Receive a MultimillionDollar Sheen', New York Times (30 December 2012), www.nytimes.com/2012/12/31/business/ media/mattel-to-give-thomas-the-tank-engine-a-multimillion-dollar-sheen.html?_r=o. Accessed 14 July 2017.

44 Barnett et al., Globalizing Responsibility, p. 125.

45 See for example, Stolle and Micheletti, Political Consumerism.

46 Wall, 'Mothers' Experience with Intensive Parenting and Brain Development Discourse'.

47 There are, however, many examples from the world of contemporary childhood where affluent children are engaged in activities that make connections with others around the world. For example, in Canada, the 'toonie, toonie' (the common name for the two-dollar coin) birthday party has become popular where children bring two toonies for the birthday girl or boy. The birthday girl or boy keeps one toonie for themselves, and donates another to charity.

48 Faircloth, Militant Lactivism?

49 A. Hochschild, The Managed Heart: The Commercialization of Human Feeling (Berkeley: University of California Press, 2014 [1983]).

50 Chen, Animacies, p. 167.

51 Chen, Animacies, pp. 170, 171.

52 Chen, Animacies, p. 188.

53 Refugee organisations in Canada reported a surge of interest in sponsorship after the publication of the photographs of Alan Kurdi (CBC, 2 September 2016, www.cbc.ca/news/canada/ manitoba/image-of-alan-kurdi-s-body-led-to-spike-in-sponsorship-of-syrian-refugeesgroup-says-1.3746552. Accessed 14 July 2017). It was soon reported that Alan Kurdi's family was trying to get to Canada. Weeks later the new Liberal government announced that they would support an increased number of Syrian refugees to Canada.

54 Suski, 'Children, Suffering and the Humanitarian Appeal'.

55 E. Langmuir, Imagining Childhood (New Haven: Yale University Press. 2006), p. 230.

56 Littler, Radical Consumption, p. 86.

57 Littler, Radical Consumption, p. 91.

58 S. Ahmed, The Cultural Politics of Emotion (New York: Routledge, 2004).

59 Cook, 'The Missing Child in Consumption Theory', p. 233.

60 Barnett et al., Globalizing Responsibility, p. 28.

61 See R. A. Wilson and R. D. Brown (eds), Humanitarianism and Suffering: The Mobilization of Empathy (New York: Cambridge University Press, 2009).

\section{References}

Ahmed, S., The Cultural Politics of Emotion (New York: Routledge, 2004).

Ariès, P., Centuries of Childhood (Harmondsworth: Penguin Books, 1960).

Babuji, H., Not Just China: The Rise of the Recall in the Age of Global Business (New York: Palgrave Macmillan, 2011). 
Barnes, B., 'Thomas the Tank Engine to Receive a Multimillion-Dollar Sheen', New York Times (30 December 2012), www.nytimes.com/2012/12/31/business/media/mattel-to-give-thomasthe-tank-engine-a-multimillion-dollar-sheen.html?_r=o. Accessed 14 July 2017.

Barnett, C., P. Cloke, N. Clarke and A. Malpass, Globalizing Responsibility: The Political Rationalities of Ethical Consumption (Hoboken: Wiley-Blackwell, 2011).

Bauman, Z., Liquid Modernity (Cambridge: Polity Press, 2000).

Bauman, Z., Consuming Life (Cambridge: Polity Press, 2007).

Bookman, S., 'Feeling Cosmopolitan: Experiential Brands and Urban Cosmopolitan Sensibilities', in D. Spencer, K. Walby and A. Hunt (eds), Emotions Matter: A Relational Approach to Emotions (Toronto: University of Toronto Press, 2012), pp. 240-59.

Bourdieu, P., Distinction: A Social Critique of the Judgement of Taste, trans. Richard Nice (Cambridge, MA: Harvard University Press, 1984).

Chen, Mel. Y., Animacies: Biopolitics, Racial Mattering, and Queer Affect (Durham, NC and London: Duke University Press, 2012).

Cook, D. T., 'The Missing Child in Consumption Theory', Journal of Consumer Culture, 8:2 (2008), pp. 219-43.

Cross, G., 'Toys', in P. Fass (ed.), Encyclopedia of Children and Childhood: In History and Society, Vol. 3 (New York: Macmillan Reference, 2004), Web Version.

Edwards, T., Contradictions of Consumption: Concepts, Practices and Politics in Consumer Society (Buckingham: Open University Press, 2000).

Faircloth, C., Militant Lactivism? Attachment Parenting and Intensive Motherhood in the UK and France (Oxford: Berghahn Books, 2013).

Frønes, I., The Autonomous Child: Theorising Socialization (New York: Springer, 2015).

Garfinkle, S., 'Choo on this', Washington Post (13 June 2007), http://voices.washingtonpost.com/ parenting/2007/06/not_the_trains.html. Accessed 14 July 2017.

Gerbaudo, P., Tweets and the Streets: Social Media and Contemporary Activism (London: Pluto Press, 2012).

Hochschild, A., The Managed Heart: The Commercialization of Human Feeling (Berkeley: University of California Press, 2014 [1983]).

Hunt, L., Inventing Human Rights: A History (New York: W. W. Norton and Company, 2007).

Langer, B., 'Commodified Enchantment: Children and Consumer Capitalism', Thesis Eleven, 69 (2002), pp. 67-81.

Langmuir, E., Imagining Childhood (New Haven: Yale University Press, 2006).

Lewis, T. and E. Potter, 'Introducing Ethical Consumption', in T. Lewis and E. Potter (eds), Ethical Consumption: A Critical Introduction (Oxon and New York: Routledge, 2013), pp. 3-24.

Littler, J., Radical Consumption: Shopping for Change in Everyday Life (Maidenhead: McGraw-Hill, Open University Press, 2009).

Nielson, L., 'Buycott or Boycott? Understanding Political Consumerism', Journal of Consumer Behaviour, 9 (2010), pp. 214-27.

Romagnoli, A. and G. Wall, ' "I know I'm a good mom”: Young, Low-Income Mothers' Experiences with Risk Perception, Intensive Parenting Ideology and Parenting Education Programmes', Health, Risk and Society, 14:3 (May 2012), pp. 273-89.

Ruckenstein, M., 'Children in Creationist Capitalism', Information, Communication and Society, 14:7 (2011), pp. 1060-76.

Schor, J., Born to Buy: The Commercialized Child and the New Consumer Culture (New York: Scribner, 2004).

Shirani, F., K. Henwood and C. Coltart, 'Meeting the Challenges of Intensive Parenting Culture: Gender, Risk Management, and the Moral Parent', Sociology, 46:1 (2012), pp. 25-40. 
Singer, P., 'Famine, Affluence and Morality', Philosophy and Public Affairs, 1:3 (Spring 1972), pp. 229-43.

Smith, A., The Theory of Moral Sentiments (Indianapolis: Liberty Fund, 1984 [1759]).

Soron, D., 'Sustainability, Self-Identity, and the Sociology of Consumption', Sustainable Development, 18:3 (2010), pp. 172-81.

Stolle, D. and M. Micheletti, Political Consumerism: Global Responsibility in Action (New York: Cambridge University Press, 2013).

Suski, L., 'Children, Suffering and the Humanitarian Appeal', in R. A. Wilson and R. D. Brown (eds), Humanitarianism and Suffering: The Mobilization of Empathy (New York: Cambridge University Press, 2009), pp. 202-22.

Suski, L., 'Humanitarianism as a Politics of Emotion', in D. Spencer, K. Walby and A. Hunt (eds), Emotions Matter: A Relational Approach to Emotions (Toronto: University of Toronto Press, 2012), pp. 124-36.

Wall, G., 'Mothers' Experience with Intensive Parenting and Brain Development Discourse', Women's Studies International Forum, 33:3 (2010), pp. 253-63.

Wilson, R. A. and R. D. Brown (eds), Humanitarianism and Suffering: The Mobilization of Empathy (New York: Cambridge University Press, 2009).

Zelizer, V. A., The Purchase of Intimacy (Princeton: Princeton University Press, 2005). 